\title{
Economic performance of the NUTS III Regions in the Czech Republic in the context of entrepreneurship subsidies from the EU Structural Funds ${ }^{* 1}$
}

\author{
Jana Kolařiková2, Ondřej Dvouletý ${ }^{3}$, Petr Kolařik ${ }^{4}$
}

\begin{abstract}
Entrepreneurship is considered to be one of the essential factors of economic growth and entrepreneurship policy is considered to be a significant contributor to the regional economic development. The aim of the present paper is to determine whether the unemployment rate and the GDP per capita of the NUTS III regions in the Czech Republic are influenced by the amount of financial subsidies paid to businesses from the Operational Programme Enterprise and Innovation (OPEI). We employed regression analysis and Granger Causality testing in order to evaluate our Hypotheses. Results from the use of econometric models confirmed statistically significant positive impact of OPEI subsidies lagged by one year on the growth of NUTS III GDP per capita. However, we were unable to confirm statistically significant initial impact of OPEI subsidies on the growth of GDP per capita. The hypothesis assuming negative impact of OPEI subsidies on changes of regional unemployment rate was statistically confirmed both initially and with a lag of one year.
\end{abstract}

Key words: regional development, regression analysis, Granger causality testing, structural funds, entrepreneurship policy

JEL classification: $R 12, R 58, L 26$, L53

* Received: 10-04-2017; accepted: 26-03-2018

1 The research has been supported by the Internal Grant Agency of the University of Economics in Prague within the project F5/69/2017 and within the project FBA no. IP300040.

2 Post-Doctoral Researcher and Lecturer, University of Economics, Prague, Faculty of Economics, Department of Regional Studies, Winston Churchill Sq. 4, 13067 Prague 3, The Czech Republic. Scientific affiliation: regional development, regional analysis. Phone: +420224095 518, Fax: +420224095 546.E-mail:xtomj38@vse.cz.

3 Post-Doctoral Researcher and Lecturer, University of Economics, Prague, Faculty of Business Administration, Department of Entrepreneurship, Winston Churchill Sq. 4,130 67 Prague 3, The Czech Republic. Scientific affiliation: entrepreneurship policy evaluation, determinants of entrepreneurship, entrepreneurial economics.Phone: +420728431 027.E-mail: ondrej.dvoulety@vse.cz.

4 PhD candidate, University of Economics, Prague, Faculty of Economics, Department of Regional Studies, Winston Churchill Sq. 4, 13067 Prague 3, The Czech Republic. Scientific affiliation: entrepreneurship/businesses, regional policy, regional development. Phone: +420 224095518 , Fax: +420224095 546.E-mail:xkolp29@vse.cz (corresponding author). 


\section{Introduction}

In general, entrepreneurship is considered to be an essential factor of economic growth in the European Union (EU) and not only there (Audretsch, 2001; Romero, 2011; Carree et al., 2007; Sternberg, 2012; Amaghouss and Ibourk, 2013; HoltzEakin and Kao, 2003; Lukeš, 2013; Šebestová et al., 2015; Holienka et al., 2016; Rusu and Roman, 2017). In this connection and in the context of a cohesion policy, which aims at stimulation of the economic growth through various activities, the importance of promoting entrepreneurship policy has significantly increased. Verheugen (2005 cited European Commission, 2015: 3) notes that "Micro, small and medium-sized enterprises (SMEs) are the engine of the European economy. They are an essential source of jobs, create entrepreneurial spirit and innovation in the EU and are thus crucial for fostering competitiveness and employment..." More flexibility when reacting to market changes and better implementation of innovation are the main, and frequently stated advantages of SMEs. As Burns (2001) notes in connection with the innovation of SMEs, these businesses offer products and services that are very different from those offered by large companies. The probability of carrying out research and development (R\&D), for example, is lower among small businesses. However, when small businesses decide to undertake a project, they seem to be more effective and faster than large companies, for example, when bringing new products onto the market. Also, Audretsch (2001) considers these enterprises to be at the forefront of the innovation process with an obvious competitive advantage. The most frequently mentioned of the problem of SMEs and new start-ups is the lack of initial financial capital, needed for expansion and growth of their businesses (e. g. Dvouletý, 2017a).

There are more than 21 million SMEs in the non-financial sector within the EU28 with almost $67 \%$ and $58 \%$ of the share on employment and gross value added (GVA) of the whole sector, respectively (European Commission, 2014). The share of people employed in SMEs in the whole business sector raised up to $60 \%$ within the Czech Republic in the year 2014. These SMEs participate in overall employment with more than a half and generate about one-third of nominal GDP of the Czech Republic (Czech Statistical Office, 2013). They are even the major employer in some regions as they absorb labour forces that have been dismissed by large companies (Veber et al., 2012).

The key element for survival, development and growth of SMEs, albeit also of other entities, is access to financial capital (Hartšenko and Sauga, 2013). Access to financial resources has also a crucial role in ensuring competitive business (Sauka, 2014). Czech businesses can use various types of subsidies when financing their activities. These subsidies can be financial or non-financial and can be provided from different sources, whether from the state budget, commercial sector or the EU. As noted by Č́mská and Klečka (2012) financial subsidy programmes can represent a further source of investment funding, such as during the crisis. 
At the EU level, and from the point of view of the promotion of entrepreneurship, the cohesion policy and structural funds constitute an essential element for the EU Member States. As the main operational programme in the Czech Republic during the programming period 2007 - 2013 Employment Operational Programme Enterprise and Innovation (OPEI) can be considered. Due to the fact that questions regarding the achievement of required goals through the cohesion policy and its effect and impact are often raised, the aim of this contribution is to ascertain whether there is any relationship between the unemployment rate and GDP of the NUTS III regions and the number of financial subsidies reimbursed to businesses in these Czech regions. The tested hypothesis assumes a positive influence of allocated financial subsidies on the economic development of the Czech regions. Particularly, we test, whether there is a positive relationship between OPEI subsidies, GDP per capita and an unemployment rate of the region. Furthermore, we are interested, whether the allocation of OPEI subsidies predicts the future economic development measured by growth of GDP per capita and unemployment rate growth.

The first part of the article focuses on a review of the literature, which helps to explain the importance of entrepreneurship in the context of regional economic development and presents former studies that are focused on the evaluation of entrepreneurship subsidies. The second part describes economic operators that benefit from OPEI and their realised projects. The third part is dedicated to the empirical analysis which is methodologically based on the estimation of econometric models and Granger causality tests to quantify the relationships among OPEI subsidies, the growth of GDP per capita and changes in unemployment rates of the thirteen Czech regions during the period of years $2008-2014$.

\section{Literature review}

Positive effects coming from the SMEs sector or entrepreneurship, in general, are very diverse. Also on this ground, the interest of regional analysis has moved from factors influencing the spatial distribution of companies to factors of creation and disappearance of companies and influence on economic growth (Mason, 1983). The significance of SMEs and their impact on economic performance of regions has become a subject of many of studies (Audretsch and Fritsch, 2002; Caves, 1998; Van Stel et al., 2005). Beck et al. (2005) identify a very strong connection of the SMEs to the GDP per capita. Van Stel et al. (2005) prove a positive impact of entrepreneurship on economic growth only within developed countries whereas when considering developing countries, they come to the opposite conclusion. Birch (1979, 1981), whose studies have strongly influenced researchers as well as politicians, concentrated his research on a role of SMEs have with respect to a job creation process. He states that, besides the SMEs, also young companies 
and start-ups are being a significant source of employment opportunities. Also, other researchers (Kirchhoff and Phillips, 1988; Broersma and Gautier, 1997; de Wit and de Kok, 2013, Klette and Mathiassen, 1996) prove, that the contribution of SMEs to the creation of employment opportunities is higher than in the case of larger companies. In contrast, Hohti (2000) comes to a conclusion that there is no verifiable relationship between a company's size and a net change of employment, i. e. the relation between numbers of newly created and lost jobs. Furthermore, there is no systematic relationship between an average company size and a number of jobs created (Friis et al., 2006). Tang and Koveos (2004) differentiate two types of entrepreneurship - innovative and venture entrepreneurship. It has been found a positive correlation with GDP growth has the first-mentioned type and a negative correlation with the latter one. The positive relationship between entrepreneurship and unemployment in a long-term (about $8-10$ years) and no relationship at all in a short-term confirms also Nyström (2008). Caves (1998) mentions also stronger impacts in the long period. From the above mentioned it is clear that business support is with regard to its impact very significant and policy support entrepreneurship should remain in the spotlight.

In case of the cohesion policy and effects of structural funds subsidies, views on the effectivity differ. As an example of a positive effect of the EU regional policy, as Vaidere (2011) notes, Ireland is presented, having a GDP per capita that increased from $64 \%$ of the European Community (EC) average during its accession in 1973 to $130 \%$ of the EU average in 2008 . An opposite example could be Greece, who's GDP per capita represented $62 \%$ of the European Community in 1983 and was not higher than the EU average (63\%) in 2003. The relationship between structural funds and GDP has been studied by Lima and Cardenete (2008), for example, who identify a positive effect of subsidies towards a regional development of Andalusia (Spain). From an effectiveness point of view, they perceive stronger effects on GDP growth in infrastructure investments that are financed by the European Regional Development Fund (ERDF), than in European Social Fund (ESF) projects (that are aimed at human capital and the promotion of employment) and agricultural projects. De La Fuente (2002) also mentions a benefit in the area of regional growth (positive effect on GDP per capita) and employment rate. Aiello and Pupo (2012) present a limited effect on the GDP per capita of Italian regions. They found no effect on a labour productivity. Pereira and Gaspar (1999) show a positive effect of structural funds on the growth of regions in Portugal. In contrast, there is a negligible effect of one of the targets of the 2007 - 2013 regional policy, i.e. convergence, on growth, as noted by Esposti and Bussoletti (2008). To sum up, no clear conclusion regarding the success and effectiveness of the structural policy can be reached. It is important to consider which regions and territorial units are analysed. Data availability also plays a major role at the regional level, but databases are often very weak. From this point of view, the research gap is still large. Given this fact and taking into account the 
circumstance that in the Czech Republic and Central and Eastern Europe similar studies are missing, we conceived our research and focused it on the impact of the financial support from the EU structural funds that aim at entrepreneurship. Our conclusions can be beneficial for the current programming period 2014+.

The year 2004 meant the new period to the Czech Republic, because of the entry to the European Union and among other things possible to draw money from Structural Funds and the Cohesion Fund. The main objective of the cohesion policy is to promote convergence among EU countries which was realized via 3 Objectives (for the impact of EU accession on the convergence in "new states" see e.g. Boronenko et al., 2014). For the programming period 2007 - 2013 the Czech Republic had allocated 26.7 billion EUR. This budget was divided among 26 Operational programmes.

\section{Methodology}

Our methodological approach is based on the quantitative research methods - we combine estimation of econometric models with testing of Granger Causality. The step by step approach is described below. We also summarize methodology of previous authors.

Inspired by the previous empirical experience and approach, we employ regression analysis to investigate the impact of the financial subsidies from OPEI on the regional economic development. The econometric approach for the evaluation of the impact of structural funds was used by e.g., Rodríguez-Pose and Fratesi (2004) or Puigcerver-Peñalver (2007). Ederveen et al. (2006) or Beugelsdijk and Eijffinger (2005) also used regression models to assess the process of convergence and effectiveness of European Cohesion Policy. Table 1 provides an overview of some European policy impact surveys through statistical methods, which document the authors' variance in the choice of the unit being analyzed, the time period, and the method used. Barro and Sala-i-Martin (1995) report that the consistency of results can be affected by significant differences between countries, so it is important for the surveyed countries to be relatively homogeneous. 
Table 1: Overview of differences in approach to economic and social cohesion policy evaluation

\begin{tabular}{|c|c|c|c|}
\hline Author & Territorial unit & Period & Method \\
\hline \multicolumn{4}{|c|}{ Countries } \\
\hline $\begin{array}{l}\text { Beugelsdijk and Eijffinger } \\
(2005)\end{array}$ & EU-15 countries & $1995-2001(2002)$ & GMM \\
\hline $\begin{array}{l}\text { Ederveen, de Groot and } \\
\text { Nahuis (2006) }\end{array}$ & $\begin{array}{l}13(12) \text { EU-15 } \\
\text { countries }\end{array}$ & $1960-1995$ & Pooled OLS, GMM \\
\hline $\begin{array}{l}\text { Crespo Cuaresma, Silgoner } \\
\text { and Ritzberger-Grünwald } \\
(2008)\end{array}$ & EU-15 countries & $1960-1998$ & OLS \\
\hline \multicolumn{4}{|c|}{ NUTS 1 and NUTS 2 unit } \\
\hline Mohl and Hagen (2008) & 124 NUTS $1 / 2$ & $1995-2005$ & LSDV,GMM \\
\hline Bussoletti and Esposti (2004) & 206 NUST 2 & $1989-2000$ & GMM \\
\hline Cappelen et al. (2003) & 105 NUTS $1 / 2$ & $1980-1997$ & OLS \\
\hline $\begin{array}{l}\text { Dall'erba and Le Gallo } \\
\text { (2008) }\end{array}$ & 145 NUTS 2 & $1989-1999$ & Spatial Regressions \\
\hline $\begin{array}{l}\text { Rodríguez-Pose and Fratesi } \\
\text { (2004) }\end{array}$ & 152 NUTS 2 & $1989-1999$ & OLS \\
\hline Puigcerver-Peñalver (2007) & 41 NUTS 2 & $1989-2000$ & OLS \\
\hline Esposti and Bussoletti (2008) & 206 NUTS 2 & $1989-2000$ & GMM \\
\hline \multicolumn{4}{|c|}{ Analysis within the state } \\
\hline Aiello and Pupo (2012) & Italy (21 NUTS 2) & $1996-2007$ & GMM, LSDV \\
\hline Eggert et al. (2007) & $\begin{array}{l}\text { Germany } \\
(16 \text { NUTS } 1)\end{array}$ & $1995-2004$ & Pooled OLS \\
\hline $\begin{array}{l}\text { Garcia-Milà and McGuire } \\
\text { (2001) }\end{array}$ & Spain (17 NUTS 2) & $1977-1992$ & $\begin{array}{l}\text { OLS, Difference in } \\
\text { Differences }\end{array}$ \\
\hline
\end{tabular}

Source: Authors' own processing based on Hagen and Mohl (2009) + Authors' own addition

The implemented approach begins by the formation of panel dataset, then we explore the stationarity of all variables and their summary statistics and then we are able to estimate econometric models, based on the most appropriate estimation technique. Our theoretical model for regression analysis is stated below in equation, where $i$ refers to a region, and $t$ to year. $\beta_{0}$ refers to constant, $\varepsilon$ represents residuals and $\mu$ accounts for fixed effects. Regional economic performance is represented by the regional GDP per capita and unemployment rate and it is a function of control variables, and OPEI subsidies.

Regional Economic Performance ${ }_{i t}=$

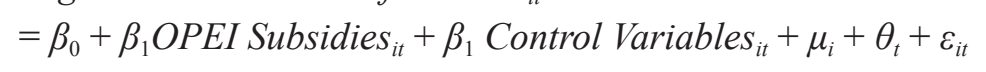


First, we form data into a panel, by combining characteristics of both, time series and cross-sectional data. Therefore, we needed to investigate, whether our variables are stationary, preventing spurious regression estimates (Granger and Newbold, 1974). To test stationarity, we employ Levin, Lin \& Chu test for panel data integrated into the software EViews 8 . The null hypothesis assumes non-stationarity of a variable and by rejecting it, we will be able to accept an alternative hypothesis of the stationarity of the variable (Levin et al., 2002).

The econometric approach applied to panel data furthermore requires deciding on the most appropriate technique of estimation. For regions/countries, fixed effects estimation are usually recommended, because legal entities usually do not change much over time (e.g. Wooldridge, 2013). To support our assumption, we test redundant fixed effects using Likelihood Ratio and the Hausman test the fixed effects are considered to be the most appropriate. Fixed effects also help us to deal with unobserved heterogeneity and they were also employed in the studies by Mohl and Hagen (2008) or Aiello and Pupo (2012). To avoid problems resulting from autocorrelation and heteroscedasticity, we estimate models with white cross-section standard errors \& covariance (d.f. corrected). In all models, we measure the level of collinearity among explanatory variables and controlled for normality of residuals (Verbeek, 2012). Tested models include delays with up to two levels, test up to a two-year effect of financial support, will be tested to verify Mohl and Hagen (2008) claiming that the impact of structural funds on growth is manifested within a two to three years.

The last part of the analysis is dedicated to testing Granger Causality, based on the approach introduced by Granger (1969). "The EU Regional Policy is a 'spatially targeted' policy: eligibility and funding are granted on the basis of geographical criteria and its outcomes are also assessed in terms of the performance of well-defined spatial units (administrative regions)" (Crescenzi and Giua, 2014: 2). The support from the structural funds should be intended to poorer regions which GDP do not exceed the $75 \%$ of the European average GDP in purchasing power parity. The effect of the support from EU is positive in less developed regions (Esposti and Bussoletti, 2008). In this case, we assume that money from structural funds which the region draw up can be influenced by the economic performance of the region. Poorest regions should draw up more than richer one but Figure 1 shows the opposite. The absorption capacity of the region which expresses the region's ability to use resources provided from EU funds plays also the big role (Cappelen et al., 2003). "Transfer treatment response heterogeneity by way of absorptive capacity as a moderator may, hence, be of first-order importance for achieving the goal of transfer programs in general and of the European Union's regional transfer programmes in specific: achieving cohesion and convergence in per capita income" (Becker et al., 2013: 30). The supply side of absorption capacity is influenced by three main factors (Šumpíková et al., 2003): macroeconomic absorption capacity, financial absorption capacity and administrative capacity. All empirical results are based on software EViews 8. 


\section{Empirical data and analysis}

As stated above, one of the operational programmes under the Czech cohesion policy realised between 2007 and 2013 was OPEI. It was the third largest Czech operational programme (with about $12 \%$ of the share on the Convergence target financial resources) that focused on the promotion of entrepreneurship, particularly in the fields of the processing industry, research and development and strategic services. The programme was intended, in line with the Community Strategic Guidelines (CSG), particularly for SMEs which play a leading role in the structure of Czech companies with a share of $99.85 \%$ on total registered active businesses (Czech Statistical Office, 2014).

Funding from OPEI was conditional on implementation of a project in the cohesion region which comes under the Objective 1 "Convergence", which covers all cohesion regions with the exception of Prague. There were 12420 decisions to award subsidies that were granted within the framework of the OPEI during the period 2007 - 2013. 89 billion Czech Crowns were paid up until February $11^{\text {th, }}$ 2016. In the case of financing of projects from structural funds, it is necessary to distinguish the location of the project (i.e., where the project is realised) and the office of the applicant for the financial support. The decision about the allocation of the financial support is based on the location of the project. However, the situation where the project has been co-financed from EU funds is realised in a different region to which the office of the applicant may happen to be located. Hájek et al. (2012) also point to this fact. For the purpose of the present paper, it is operated with data on the location of the project. About $16 \%$ of projects were realised in a region that was different to the location of the office of whoever was applying for EU support. Some applicants submitted more applications concerning subsidy under OPEI. Boháčková and Svatošová (2012: 116) note that regions entering competitive relationships and regions in which applicants are good at submitting meaningful projects and have their existing appearance with the administration of EU projects are successful. Some regions that do not have such experience, sometimes do not receive the subsidy although they have necessary projects.

Figure 1 shows a number of projects per number of businesses which were realised in the Czech regions and a percentage share of the subsidies paid in Czech Crowns on the total subsidy amount paid from OPEI. As can be seen from Figure 1, resources are unequally distributed among Czech regions and the largest amount of subsidies was allocated mostly in Moravia and Silesia and also in Central Bohemian region. Because of the subsidy from the EU is intended for poorer regions and should reduce regional disparities, in this case, the question about the effectivity of this support appeared. Central Bohemian region and also South Moravian region do not have the lower GDP but are on the top of this indicator. This is also one of the reasons for conducting this research. 
Figure 1: The number of OPEI projects in the Czech NUTS III regions and \% share of the total amount of subsidy from OPEI in the Czech regions from OPEI

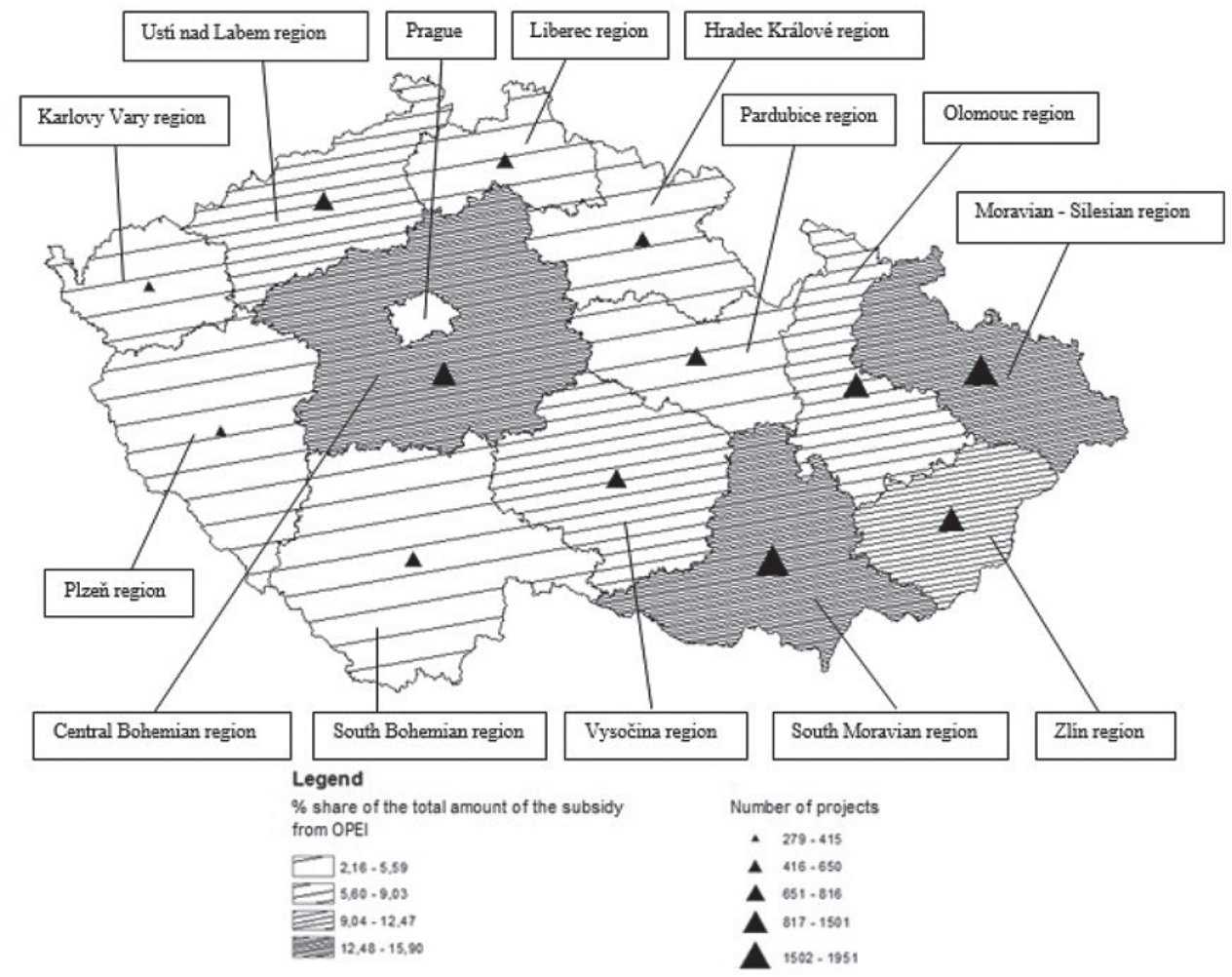

Source: Authors' own calculation and data-processing from CzechInvest (2016)

It is necessary to remark that regions have different land areas, different population numbers, and different numbers of business subjects, hence the number of projects realised in the region was recalculated per business subject. The highest number of OPEI projects per number of businesses was realised in Zlín region. The least number of projects per number of businesses was realised in Plzeň region. The high number of businesses and lowest number of projects between Czech regions can be one of the reasons for this (i.e., in the Plzen region there are many businesses with foreign participation - the number of these business exceeds twice the national average). Within OPEI there were announced calls within programmes with a different focus, e.g., real estate, ICT, innovation, etc. It is noteworthy that some of the programmes of support are intended for some specific regions, e.g., projects from the programme of support under the auspices of Development could be realised only in the regions with concentrated stated aid or in the regions with the higher unemployment rate, which were defined in the call for support. As Wokoun et al. (2016) note, there were more than $37 \%$ of all OPEI projects that were realised 
in the regions with concentrated state aid. About $33 \%$ of the total volume of subsidies under OPEI was paid out in these projects. If we only take into account the Development programme, then the percentage is higher. In this survey, an effort to support the above-mentioned regions was confirmed. Also, Felixová (2012), who analysed 1,455 projects from OPEI, achieved the same conclusion. Smékalová et al. (2015) dealt with the spatial concentration of the projects that were co-financed from the EU in special intervention areas within the Czech Republic and Poland. They concluded (2015: 222) that "the regions with the concentrated state support are not so apparently promoted in the operational programmes documents as the leading beneficiaries from the cohesion policy with the exception of a single operational programme targeting the entrepreneurs."

In this context, it is beneficial to evaluate whether there is some relationship between the subsidy from OPEI and the unemployment rate and the GDP of Czech regions. Managing authorities of Operational programmes mostly evaluated the success of the programme through a system of indicators, which are basically represented by a table of numbers having limited information value. One of the indicator the number of realised new jobs is. But the Supreme Audit Office (2016) notes in the report that the achievement of results, e.g. in form of creating of new jobs, was not compulsory and the Ministry of Industry and Trade did not control it. It should be created more than 48 thousand jobs from the OPEI, but in the fact, the number of newly created jobs is much lower. The Ministry of Industry and Trade did not verify if the value of the showed indicators is true, so their information ability is very limited. Supreme Audit Office verify the validity of aggregated data and found out imperfections in showed data showed from OPEI applicants (Supreme Audit Office, 2016). It is also one of the reasons why we do not evaluate the impact on the number of newly created jobs, but we chose the unemployment rate. It is practically impossible to separate the impact of the support from EU funds from other influences affecting economic development. In the connection with implemented projects and their impacts, it is also necessary to mention the potential threat of deadweight loss that represents the situation where projects would be implemented sooner or later without the subsidy. A team comprising the researchers Wokoun et al. (2016) undertook a questionnaire survey among 5,832 applicants from the Operational Programme Enterprise and Innovation at the end of 2014. This survey showed that most of the projects will be implemented without subsidy $(60 \%)$ so that applicants do not condition their realisation of the projects by the existence of EU subsidy policy. Answers to the question about there should be an implementation of the project without EU support were as follows: $45.27 \%$ said probably yes; $32.62 \%$ said that they somewhat disagree, $15.71 \%$ said definitely yes; $6.39 \%$ said definitely not. It raises a challenge for managing authorities of operational programmes to take this question in the approval of projects in order to avoid the situation that it will be implementing projects which will be also implemented without any EU subsidy. 
This section is also dedicated to the introduction of the stated hypotheses, collected data and testing for stationarity. Due to the termination of the 2007 - 2013 programming period, the aim is to find out if there is any relationship between the economic performance of the NUTS III regions in the Czech Republic and the number of financial subsidies paid to businesses from the Operational Programme Enterprise and Innovation (OPEI). When analysing the economic performance, following indicators have been chosen: the growth of GDP per capita, unemployment rate growth and net disposable income of households. Despite the fact that some disadvantages of the indicator of GDP, this particular indicator is used as the main criteria in decision making about the rightfulness of drawing the subsidy from the European Union (EU). One of the limitations of this index, e.g., the influence of commuting, existence of shadow economy is that unemployment rate is often considered to be an indicator revealing regional problems and the indicator which reflects the economic situation of the region.

Taking into consideration that the aim of cohesion policy is particularly to lower regional disparities through the increase of entrepreneurial activity, we assume a positive relationship between the paid subsidies and the economic performance of the region. More formally, the following hypotheses are therefore to be tested:

- Hypothesis $1(\mathrm{H} 1)$ : There is a positive relationship between OPEI subsidies and growth of GDP per capita of the region.

- Hypothesis 2 (H2): There is a negative relationship between OPEI subsidies and changes in an unemployment rate of the region.

- Hypothesis 3 (H3): OPEI subsidies predict the future economic development measured by growth of GDP per capita and unemployment rate growth.

To evaluate the stated hypothesis, we use an econometric approach, which includes panel regression estimates with Fixed Effects and Granger causality tests based on collected data that are introduced in the next section.

The dataset was obtained from various sources and in this section, we introduce the variables. The collected series is for 13 regions of the Czech Republic that are supported by OPEI and for a period of years 2008 - 2014 and the dataset are strongly balanced. The analysed period starts from 2008 because after receiving a subsidy, it takes time for subjects to actually realise their project. The Prague region was excluded from the analysis because the programme was not applied there. The unemployment rate that is expressed in percentages (UNEMPLOYMENT_RATE), GDP per capita in Czech crowns (GDP_PER_CAPITA) and net disposable income of households $(N D I H)$ were obtained from the Czech Statistical Office (Czech Statistical Office, 2016). The financial amount of subsidies in Czech Crowns that was transferred to regions from OPEI (OPEI_SUBSIDIES) was obtained from the Czech Ministry of Industry and Trade (MPO, 2016). To adjust series for inflation and to convert them 
into real series, we used a GDP deflator with the base year of 2010, obtained from Eurostat (2016a). Financial subsidies were also recalculated per capita in order to allow cross-region comparisons. Descriptive statistics are presented in Table 2. Based on these data were calculated variables representing percentage growth of the real GDP per capita (REAL_GDP_PER_CAPITA_GROWTH) and percentage change of unemployment rate (UNEMPLOYMENT_RATE_GROWTH).

Table 2: Descriptive statistics

\begin{tabular}{|l|r|r|r|r|r|c|}
\hline \multicolumn{1}{|c|}{ Variable } & \multicolumn{1}{c|}{ Mean } & \multicolumn{1}{c|}{ Median } & Maximum & Minimum & Std. Dev. & Observations \\
\hline $\begin{array}{l}\text { OPEI_SUBSIDIES } \\
\text { (mil. CZK) }\end{array}$ & 609 & 464 & 2440 & 0.000 & 608 & 91 \\
\hline NDIH (CZK) & 186989.8 & 185022.0 & 218503.0 & 166736.0 & 11210.21 & 91 \\
\hline $\begin{array}{l}\text { UNEMPLOYMENT_ } \\
\text { RATE (\%) }\end{array}$ & 6.998 & 6.972 & 11.156 & 2.600 & 2.014 & 91 \\
\hline $\begin{array}{l}\text { GDP_PER_CAPITA } \\
(\text { CZK) }\end{array}$ & 320877.8 & 320403.0 & 397233.0 & 269200.0 & 27711.97 & 91 \\
\hline
\end{tabular}

Note: The average exchange rate during the analysed period 2007-2014 was 27.54 EUR/CZK (Eurostat, 2016b).

Source: EViews, the authors' own elaboration

To test stationarity, we employed Levin, Lin \& Chu test for panel data integrated into the software EViews 8. Results of stationarity testing are described in Table 3. Not all variables were found to be stationary, therefore we used a logarithmic transformation to stabilise variables (Verbeek, 2012). Additional testing revealed that all adjusted variables are stationary and therefore, we were able to use them for econometric modelling.

Table 3: Stationarity testing

\begin{tabular}{|l|c|c|c|}
\hline \multicolumn{1}{|c|}{ Variable } & P-Value & Stat. Significance & Result \\
\hline REAL_OPEI_SUBSIDIES_CAP & 0.14 & $5 \%$ & Non-stationary \\
\hline LN_R_OPEI_SUBSIDIES_CAP & 0.00 & $5 \%$ & Stationary \\
\hline REAL_NDIH & 0.00 & $5 \%$ & Stationary \\
\hline LN_R_NDIH & 0.00 & $5 \%$ & Stationary \\
\hline REAL_NDIH_GROWTH & 0.00 & $5 \%$ & Stationary \\
\hline UNEMPLOYMENT_RATE & 0.00 & $5 \%$ & Stationary \\
\hline UNEMPLOYMENT_RATE_GROWTH & 0.00 & $5 \%$ & Stationary \\
\hline REAL_GDP_PER_CAPITA & 0.00 & $5 \%$ & Stationary \\
\hline LN_R_GDP_PER_CAPITA & 0.00 & $5 \%$ & Stationary \\
\hline REAL_GDP_PER_CAPITA_GROWTH & 0.00 & $5 \%$ & Stationary \\
\hline
\end{tabular}

Source: Eviews, the authors' own elaboration 
Next part presents the obtained econometric estimates. In the first econometric model (Model 1) we have confirmed the statistically significant positive relationship between the OPEI subsidies and the GDP per capita. Also, the negative relationship between the unemployment rate and regional GDP per capita was confirmed on an initial level in Model 1. However, in order to investigate the impact of OPEI subsidies on economic development, we needed to analyse the dynamics of GDP per capita (in Model 2 and Model 3) and the unemployment rate (in Model 4 and Model 5). The results are controlled for level of GDP per capita and unemployment rate depending on the explained variable in the model.

The two following regression estimates of Model 2 and Model 3 served as a tool to evaluate the main hypothesis that subsidies transferred to entrepreneurs lead to an increase in the economic welfare of the region. In Model 2, testing the initial effect of OPEI subsidies on the growth of real GDP per capita, we were unable to prove any statistical significance of the variable representing OPEI subsidies even though the coefficient indicated a positive impact. However, a statistically significant result was obtained when using a one year lagged variable representing OPEI subsidies in Model 3, supporting H1. We, therefore, conclude, that according to our results it takes up to one year for OPEI subsidies to positively affect the economic growth of the region as measured by growth of real GDP per capita.

Table 4: Model table

\begin{tabular}{|c|c|c|c|c|c|}
\hline Variable / Model & Model 1 & Model 2 & Model 3 & Model 4 & Model 5 \\
\hline Dependent Variable & $\begin{array}{l}\text { LN_R_GDP_ } \\
\text { PER_CAPITA }\end{array}$ & \multicolumn{2}{|c|}{$\begin{array}{l}\text { REAL_GDP_PER_ } \\
\text { CAPITA_GROWTH }\end{array}$} & \multicolumn{2}{|c|}{$\begin{array}{l}\text { UNEMPLOYMENT } \\
\text { RATE_GROWTH } \\
\end{array}$} \\
\hline \multirow{2}{*}{$\begin{array}{l}\text { LN_R_OPEI_- } \\
\text { SUBSIDIES_CAP }\end{array}$} & $0.0054 * * *$ & 1.7546 & & $-18.7779 * * *$ & \\
\hline & $(0.0014)$ & $(1.4106)$ & & $(3.7534)$ & \\
\hline \multirow{2}{*}{$\begin{array}{l}\text { LN_R_OPEI_ } \\
\text { SUBSIDIES_CAP }(-1)\end{array}$} & & & $0.7856 * * *$ & & $-7.6117 * * *$ \\
\hline & & & $(0.1755)$ & & $(1.2465)$ \\
\hline \multirow{2}{*}{$\begin{array}{l}\text { UNEMPLOYMENT_ } \\
\text { RATE }\end{array}$} & $-0.0147 * * *$ & -0.1556 & -0.500141 & & \\
\hline & $(0.002)$ & $(0.7652)$ & $(0.442181)$ & & \\
\hline \multirow{2}{*}{$\begin{array}{l}\text { LN_R_GDP_PER_- } \\
\text { CAPITA }\end{array}$} & & & & $-369.4981 * * *$ & $-248.8599 * *$ \\
\hline & & & & $(115.7921)$ & $(110.0551)$ \\
\hline \multirow{2}{*}{ CONSTANT } & $12.7348^{* * *}$ & -10.2293 & -0.4015 & $4811.422 * * *$ & $3201.804 * *$ \\
\hline & $(0.0156)$ & $(13.7874)$ & $(3.7814)$ & $(1450.045)$ & $(1386.131)$ \\
\hline R-squared & 0.929 & 0.223 & 0.406 & 0.616 & 0.701 \\
\hline Adj. R-squared & 0.916 & 0.050 & 0.274 & 0.530 & 0.634 \\
\hline F-statistic & 71.05 & 1.29 & 3.07 & 7.20 & 10.54 \\
\hline Observations & 78 & 78 & 78 & 78 & 78 \\
\hline
\end{tabular}

Note: Standard Errors are in parentheses $* * *$ stat. significance at $1 \%, * *$ stat. significance at $5 \%$, * stat. significance at $10 \%$.

Source: EViews, the authors' own elaboration 
Models 4 and 5 were estimated in order to evaluate $\mathrm{H} 2$, investigating the effect of OPEI subsidies on changes in the regional unemployment rate. In both models, we find a statistically significant negative impact of OPEI subsidies on unemployment rate growth, confirming $\mathrm{H} 2$. Therefore, we conclude, that OPEI subsidies led to decrease of the unemployment rate for the NUTS III regions during the period analysed. Finally, we tried to measure the impact of OPEI subsidies on changes in net disposable income of households $(N D I H)$. Results suggested positive impact, however, they were also statistically insignificant.

According to Figure 1 and the above mentioned, we have tested how well the allocation of OPEI subsidies can predict the future economic development of the region in terms of the growth of real GDP per capita and the growth of unemployment rate using up to two-year lags. The results are presented in Table 5.

Table 5: Granger causality

\begin{tabular}{|l|c|c|l|}
\hline \multicolumn{1}{|c|}{ Tested Relationship } & P-value & Lags & H0 Reject \\
\hline $\begin{array}{l}\text { LN_R_OPEI_SUBSIDIES_CAP } \rightarrow \text { REAL_GDP_CAPITA_ } \\
\text { GROWTH }\end{array}$ & 0.04 & 2 & Rejected \\
\hline $\begin{array}{l}\text { REAL_GDP_CAPITA_GROWTH } \rightarrow \text { LN_R_OPEI } \\
\text { SUBSIDY_CAP }\end{array}$ & 0.40 & 2 & Not Rejected \\
\hline $\begin{array}{l}\text { LN_R_OPEI_SUBSIDIES_CAP } \rightarrow \text { UNEMPLOYMENT_ } \\
\text { RATE_GROWTH }\end{array}$ & 0.02 & 2 & Rejected \\
\hline $\begin{array}{l}\text { UNEMPLOYMENT_RATE_GROWTH } \rightarrow \text { LN_R_OPEI_- } \\
\text { SUBSIDY_CAP }\end{array}$ & 0.74 & 2 & Not Rejected \\
\hline
\end{tabular}

Source: EViews, the authors' own elaboration

At the 5\% level of statistical significance we were able to reject the null hypothesis of a non-existence Granger causality relationship between the real OPEI subsidies per capita and the growth of real GDP per capita (one way), concluding that OPEI subsidies predicted (Granger caused) the future development of the real GDP per capita in the region. A one-way relationship in the sense of Granger causality was also confirmed for the real OPEI subsidies per capita and the unemployment rate growth, concluding that OPEI subsidies allocation predicted (Granger caused) future development of unemployment rate in the region confirming our third stated hypothesis (H3).

\section{Results and discussion}

Since this study was the first to investigate the impact of the OPEI programme in the Czech Republic, the obtained results may be compared only with the results obtained by scholars from other countries. Studies focused on the efficiency of 
the impact of structural funds have not provided conclusive findings so far (e.g., Garcia-Milà and McGuire, 2001; Rodríguez-Pose and Fratesi, 2004; Dall'erba and Le Gallo, 2008; Lima and Cardenete, 2008; Ionescu and Tudor, 2011; Aiello and Pupo, 2012). The short-run positive relationship between subsidies from EU Structural Funds and regional economic growth report is reported by, for instance, Eggert et al. (2007). One of the possible explanations for the positive impact, besides the entrepreneurial activity (Dvouletý, 2017b; 2017c; Dvouletý and Lukeš, 2016 or Dvouletý and Mareš, 2016), is also the multiplier effect that the implemented projects can bring.

The HERMIN model that was created for the purpose of assessment of structural funds, also assumes this effect. The Fifth report on economic, social and territorial cohesion provides information about the positive impact of subsidies on the level of GDP, and on its growth, both in the short- and long-term. The presented results also report positive outcomes on employment (European Commission, 2010). A contradictory finding was, for example, obtained by Mohl and Hagen (2010) who mention that only subsidies from Objective 1 result in higher regional economic growth. A similar result was obtained by Gómez-García et al. (2012), who also state that only subsidies from Objective 1 result in higher regional employment rates.

The positive impact of structural funds on employment rates was also described by the National Training Fund (2010). These conclusions correspond with the findings of Martin and Tyler (2006) who estimated a significant contribution of structural funds on Objective 1 regions' employment. These conclusions also correspond with the findings of Cancelo et al. (2009) who notes the significant effect of structural funds on employment in the Objective 1 region of Galicia. One explanation for the obtained results could be that more than one-half of the financial resources of the programme were paid under programmes Development, Innovation and Real estates, with a focus on investments. For instance, the aim of the Development Programme was particularly to obtain new technological equipment with higher technical and utility parameters. The acquisition of new equipment implies a need for new employees who will operate the equipment. The aim of the Real Estates Programme was to support modern production operations via the construction of essential infrastructure or the regeneration of brownfields and in some cases construction on green fields. New or refurbished enterprises also need new employees, which can cause a reduction of unemployment rate. In the context of the creation of new jobs, it is necessary to mention that not all projects serve in the creation of new jobs. Sometimes, a European Union (EU) co-financed project can lead to job reductions, due to a modernisation and automation of production, with the replacement of human resources by machines. Projects sometimes have indirect effects which can be positive, but sometimes they can also be negative. The results obtained by Florio and Moretti (2014), suggest that direct support for businesses by the European Cohesion Policy contributes to the growth process of employment in different industries. 
Our findings are not without limitations. Both regional unemployment rate and GDP per capita changes are affected by other regional policies and factors that we were unable to put into our regression estimates, because it is not possible to cover all different regional policies and to collect comparable data for them across regions cover all different regional policies and to collect comparable data for them across regions. The endogeneity caused by these interdependencies can influence results of our research. E.g. Bradley and Untiedt (2008) mention that the quality of institutions has a significant impact on growth. Martin (2003) notes that structural funds can foster the growth but a stable institutional structure and macroeconomic environment are significant. Bähr (2008) mention the degree of decentralization. We also mentioned the absorption capacity.

Furthermore, more frequent data, such as monthly data, could provide more detailed information and open up a pathway to more sophisticated econometric methods. One of these could be, for example, Vector Autoregression (VAR), allowing construction of impulse response functions determining the response of variable (in our case growth of GDP per capita and changes of unemployment rate) after unit shock (OPEI subsidies) over time. For more accurate results, one had better focus on smaller units such as LAU 1 regions because NUTS III units consist of more LAU 1 units which are very different. Unfortunately, statistical data for LAU 1 units are not available. With more observations, one could also include in the analysis additional control variables, and test whether the presented results are stable. Notwithstanding the number of limitations and potential drawbacks, we believe that our analysis may inspire future researchers to conduct empirical evaluations more frequently. Also, we stress the importance of data collection by policymakers and also the importance of cooperation between research institutions and public sector authorities.

\section{Conclusions}

Evaluation of the success of economic, social and territorial cohesion can be very difficult because it involves the existence of many other influences that cannot be completely eliminated. This research was undertaken in the context of the need for evaluation of Czech entrepreneurship policies that are funded from the European Union, specifically from the Operational Programme Enterprise and Innovation (OPEI) that lasted during the period of 2007 - 2013. Particularly, we analysed the effect of the third largest Czech operational programme on the economic performance of Czech NUTS III regions. Our research interest was expressed via three hypotheses, firstly testing the positive relationship between OPEI subsidies and growth of GDP per capita of the NUTS III regions. Secondly, we investigated the impact on changes of the unemployment rate by employing regression analysis. Thirdly, we aimed at knowing to what extent is OPEI 
subsidies good predictor of future regional economic development in terms of Granger causality.

The results of our econometric models confirmed a statistically significant positive impact of OPEI subsidies lagged by one year on the growth of NUTS III' GDP per capita. A statistically significant result was however not obtained on the initial level of OPEI subsidies. The hypothesis that assumes a negative impact of OPEI subsidies on changes of the regional unemployment rate was statistically confirmed initially and also with a lag of one year. Therefore, it may take time for companies to order new facilities/machines and to prepare them for being operational. However new employees need to be trained before the facilities are ready and also some of them could be recruited because employees with specific human capital are requested to be within the company as consequence of planned or just implemented innovations. Regression estimates for testing the impact of OPEI subsidies on the net disposable income of households indicated a positive impact, but could not be statistically proven. Finally, the results of Granger causality testing of the predictive power of OPEI subsidies on regional economic development revealed, that OPEI subsidies are a good predictor of future regional economic development in terms of growth of GDP per capita and changes of the unemployment rate.

Our conclusion is that OPEI contributed to the economic development of NUTS III regions during the period analysed. Of course, the presented analysis does not suffer from limitations that need to be taken into account. However, we believe that our analysis serves as an inspiration and a driver for future researchers to conduct empirical evaluations more frequently. We also stress the importance of cooperation between researchers and public sector authorities during the assessment process. The results of our analysis have cast light on OPEI outcomes and could be a very useful tool for future counterfactual analysis with Operational Programme Enterprise and Innovations for Competitiveness (OPEIC) for the programme period 2010 - 2014. The methodology used could also be applied to any remaining programmes that aiming at regional employment, such as Operational Programme Human Resources (OPHR).

\section{References}

Aiello, F., Pupo. V. (2012) "Structural funds and the economic divide in Italy", Journal of Policy Modeling, Vol. 34, No. 3, pp. 403-418, doi: 10.1016/j. jpolmod.2011.10.006.

Amaghouss, J., Ibourk, A. (2013) "Entrepreneurial Activities, Innovation and

Economic Growth: The Role of Cyclical Factors Evidence from OECD Countries for the Period 2001-2009", International Business Research, Vol. 6, No. 1, pp. 153-162, doi: 10.5539/ibr.v6n1p153. 
Audretsch, D. B. (2001) "Research Issues Relating to Structure, Competition, and Performance of Small Technology-Based Firms", Small business economics, Vol. 16, No. 1, pp. 37-51, doi: 10.1023/A:1011124607332.

Audretsch, D. B., Fritsch, M. (2002) "Growth Regimes over Time and Space", Regional Studies, Vol. 36, No. 2, pp. 113-124, doi: 10.1080/00343400220121909.

Bähr, C. (2008) "How does Sub-National Autonomy Affect the Effectiveness of Structural Funds?", Kyklos, Vol. 61, No. 1, pp. 3-18, doi: 10.1111/j.1467-6435. 2008.00389.x.

Barro, R.J., Sala-i-Martin, X. (1995) Economic Growth, New York: McGraw-Hill.

Beck, T., Demirguc-Kunt, A., Levine, R. (2005) "SMEs, Growth, and Poverty: Cross-Country Evidence", Journal of Economic Growth, Vol. 10, No. 3, pp. 199-229, doi: 10.1007/s10887-005-3533-5.

Becker, S. O., Egger, P. H., von Ehrlich, M. (2013) “Absorptive Capacity and the Growth and Investment Effects of Regional Transfers: A Regression Discontinuity Design with Heterogeneous Treatment Effects", American Economic Journal: Economic Policy, Vol. 5, No. 4, pp. 29-77, doi: 10.1257/ pol.5.4.29.

Beugelsdijk, M., Eijffinger, S. C. W. (2005) "The Effectiveness of Structural Policy in the European Union: An empirical Analysis for the EU-15 in 1995-2001", Journal of Commnon Market Studies, Vol. 43, No. 1, pp. 37-51, doi: 10.1111/j.0021-9886.2005.00545.x.

Birch, D. L. (1979) The Job Generation Process, MA: MIT Program on Neighborhood and Regional Change.

-------- (1981) "Who Creates Jobs?", The Public Interest, Vol. 65. [Internet] Available at $<$ http://www.nationalaffairs.com/doclib/20080708_1981651whocr eatesjobsdavidlbirch.pdf> [Accessed: January 2, 2016].

Boháčková, I., Svatošová, L. (2012) “Regionální konkurenceschopnost, prosperita a dynamika rozvoje - jejich smysluplnost $\mathrm{v}$ kontextu politiky hospodárské a sociální soudržnosti EU”. In Klímová, V., Žítek, V. (eds.), XV. Mezinárodni kolokvium o regionálnich vědách. Sborník přispěvkủ. Brno: Masarykova univerzita, pp. 112-119.

Boronenko, V., Mensikovs, V., Lavrinenko, O. (2014) "The impact of EU accession on the economic performance of the countries' internal (NUTS 3) regions", Zbornik Radova Ekonomskog Fakulteta u Rijeci-Proceedings of Rijeka Faculty of Economics, Vol. 32, No. 3, pp. 313-341, doi: 10.18045/zbefri.

Bradley, J., Untiedt, G. (2008) "EU cohesion policy and "conditional" effectiveness: What do cross-section regressions tell us?", GEFRA Working Paper, No. 4.

Broersma, L., Gautier, P. (1997) "Job Creation and Job Destruction by Small Firms: An Empirical Investigation for the Dutch Manufacturing Sector", Small Business Economics, Vol. 9, No. 3, pp. 211-224, doi: 10.1023/a:1017982719207. 
Burns, P. (2001) Entrepreneurship and Small Business, New York: Palgrave Macmillan.

Bussoletti, S., Esposti, R. (2004) "Regional Convergence, Structural Funds and The Role of Agriculture in the European Union. A panel-data approach", Universita Politecnica delle Marche, Dipatimento die Economia Working Paper, No. 220.

Cancelo, J. R., Faíña, J. A., López-Rodríguez, J. (2009) "Measuring the Permanent Impact of European Structural Funds on Peripheral Objective 1 Regions: The Case of Galicia", European Planning Studies, Vol. 17, No. 10, pp. 1535-1558, doi: 10.1080/09654310903141771.

Cappelen, A., Castellacci, F., Fagerberg, J., Verspagen, B. (2003) "The Impact of EU Regional Support on Growth and Convergence in the European Union", Journal of Common Market Studies, Vol. 41, No. 4, pp. 621-644, doi: 10.1111/1468-5965.00438.

Carree, M., Van Stel, A., Thurik, R., Wennekers, S. (2007) "The relationship between economic development and business ownership revisited", Entrepreneurship and Regional Development, Vol. 19, No. 3, pp. 281-291, doi: 10.1080/08985620701296318.

Caves, R. E. (1998) "Industrial Organization and New Findings on the Turnover and Mobility of Firms", Journal of Economic Literature, Vol. 36, No. 4, pp. 1947-1982.

Crescenzi R., Giua, M. (2014) "The EU Cohesion policy in context: regional growth and the influence of agricultural and rural development policies", LSE 'Europe in Question'Discussion Paper Series. No. 85, doi: 10.2139/ssrn.2542244.

Crespo Cuaresma, J., Silgoner, M. A., Ritzberger-Grünwald, D. (2008) "Growth, convergence and EU membership", Applied Economics, Vol. 40, No. 5, pp. 643-656, doi: 10.1080/00036840600749524.

CzechInvest (2016) "Seznam podpořených projektů OPPI", [Internet] Available at: $<$ http://www.czechinvest.org/seznam-podporenych-projektu-oppi> [Accessed: June 30, 2014].

Czech Statistical Office (2013) "Malé a střední firmy v ekonomice ČR v letech 2003 - 2010", [Internet] Available at: <http://www.czso.cz/csu/2011edicniplan. nsf/p/1161-11> [Accessed: December 15, 2015].

Czech Statistical Office (2014) "Veřejná databáze", [Internet] Available at: <http:// vdb.czso.cz/vdbvo/uvod.jsp> [Accessed: December 1, 2014].

Czech Statistical Office (2016) "Veřejná databáze", [Internet] Available at: $<$ https:// vdb.czso.cz/vdbvo2/> [Accessed: January 11, 2016].

Č́mská, D., Klečka, J. (2012) "Investment Activities of Businesses and the Use of European Financial Support in the Czech Republic at the Time of Crisis", Theoretical and applied Economics, Vol.19, No. 4, pp. 17-30.

Dall'erba, S., Le Gallo, J. (2008) "Regional convergence and the impact of European structural funds over 1989-1999: A spatial econometric analysis", Papers in 
Regional Science, Vol. 87, No. 2, pp. 219-244, doi: 10.1111/j.1435-5957.2008. 00184.x.

De La Fuente, A. (2002) "The effect of structural funds on the Spanish regions: An assessment of the 1994-1999 Objective 1 CSF", [Internet] Available at: <http:// cepr.org/active/publications/discussion_papers/dp.php?dpno=3673 $>$ [Accessed: December 10, 2015].

De Wit, G., de Kok, J. (2013) "Do small businesses create more jobs? New evidence for Europe", Small Business Economics, Vol. 42, No. 2, pp. 283-295, doi: 10.1007/s11187-013-9480-1.

Dvouletý, O. (2017a) "Effects of Soft Loans and Credit Guarantees on Performance of Supported Firms: Evidence from the Czech Public Programme START“, Sustainability, Vol. 9, No. 12, pp. 2293, doi: 10.3390/su9122293.

- (2017b) "Can policy makers count with positive impact of entrepreneurship on economic development of the Czech regions? “, Journal of Entrepreneurship in Emerging Economies, Vol. 9, No. 3, pp. 286-299, doi: 10.1108/jeee-11-20160052 .

(2017c) "Determinants of Nordic entrepreneurship", Journal of Small Business and Enterprise Development, Vol. 24, No. 1, pp. 12-33, doi: 10.1108/ jsbed-07-2016-0104.

Dvouletý, O., Lukeš, M. (2016) “Review of Empirical Studies on Self-Employment out of Unemployment: Do Self-Employment Policies Make a Positive Impact?", International Review of Entrepreneurship, Vol. 14, No. 3, pp. 361376.

Dvouletý, O., Mareš, J. (2016) "Determinants of Regional Entrepreneurial Activity in the Czech Republic", Economic Studies \& Analyses/Acta VSFS, Vol. 10, No. 1, pp. 31-46.

Ederveen, S., de Groot H. L. F., Nahuis, R. (2006) "Fertile Soil for Structural Funds? A Panel Data Analysis of the Conditional Effectiveness of European Cohesion Policy“, Kyklos, Vol. 59, No. 1, pp. 17-42, doi: 10.1111/j.1467-6435. 2006.00318.x.

Eggert, W., Von Ehrlich, M., Fenge, R., König, G. (2007) "Konvergenz- und Wachstumseffekte der europäischen Regionalpolitik in Deutschland", Perspektiven der Wirtschaftspolitik, Vol. 8, No. 2, pp. 130-146, doi: 10.1111/j. 1468-2516.2007.00237.x.

Esposti, R., Bussoletti, S. (2008) "Impact of Objective 1 Funds on Regional Growth Convergence in the European Union: A Panel-data Approach", Regional Studies, Vol. 42, No. 2, pp. 159-173, doi: 10.1080/00343400601142753.

European Commission (2010) "Panorama. Hodnocení regionální politiky. Náhledy s výsledky", No.3, [Internet] Available at: <http://ec.europa.eu/regional_policy/ sources/docgener/panorama/pdf/mag33/mag33_cs.pdf $>$ [Accessed: January 22, 2016]. 
------ (2014) "Annual report on European SMEs 2013/2014 - a partial and fragile recovery", [Internet] Available at: <http://ec.europa.eu/enterprise/policies/sme/ facts-figures-analysis/performance-review/files/supporting-documents/2014/ annual-report-smes-2014_en.pdf $>$ [Accessed: January 15, 2016].

(2015) "The new SME definition: user guide and model declaration", [Internet] Available at: <http://www.eusmecentre.org.cn/sites/default/files/files/ news/SME\%20Definition.pdf> [Accessed: January 10, 2016].

Eurostat (2016a) "Database", [Internet] Available at: <http://ec.europa.eu/eurostat/ data/database> [Accessed: January 10, 2016].

(2016b) "Nominal Exchange Rate CZK/EUR", Available at: < http://ec. europa.eu/eurostat/data/database $>$ [Accessed: December 22, 2017].

Felixová, K. (2012) “Zhodnocení intenzity absorpce podpory podnikání v regionech se soustředěnou podporou státu”, Ekonomie a Management, Vol. 15, No. 1, pp. $17-27$.

Florio, M., Moretti, L. (2014) "The Effect of Business Support on Employment in Manufacturing: Evidence from the European Union Structural funds in Germany, Italy and Spain", European Planning Studies, Vol. 22, No. 9, pp. 1802-1823, doi: 10.1080/09654313.2013.805731.

Friis, C., Karlsson, C., Paulsson T. (2006) "Relating Entrepreneurship to Economic Growth" In Johansson B., Karlsson C., Stough R., The Emerging Digital Economy: Entrepreneurship, Clusters and Policy, Springer-Verlag Berlin Heidelberg, pp. 83-111, doi: 10.1007/3-540-34488-8_5.

Garcia-Milà, T., McGuire, T. J. (2001) "Do Interregional Transfers Improve the Economic Performance of Poor Regions? The Case of Spain", International Tax and Public Finance, Vol. 8, No. 3, pp. 281-296, doi: 10.1023/a:1011264107134.

Granger, C. W. J. (1969) "Investigating Causal Relations by Econometric Models and Cross-spectral Methods", Econometrica: Journal of the Econometric Society, Vol.37, No.3, pp. 424-438, doi: 10.2307/1912791.

Granger, C. W. J., Newbold, P. (1974) “Spurious regressions in econometrics”, Journal of Econometrics, Vol. 2, No. 2, pp. 111-120.

Gómez-García, J., Moreno Enguix, M., Gómez-Gallego, J. C. (2012) "Estimation of the efficiency of structural funds: a parametric and nonparametric approach", Applied Economics, Vol. 44, No. 30, pp. 3935-3954, doi: 10.1080/00036846. 2011.583224.

Hagen T., Mohl P. (2009) "Econometric evaluation of EU Cohesion Policy: a survey", ZEW Discussion Papers 09-052, [Internet] Available at: <http://ftp. zew.de/pub/zew-docs/dp/dp09052.pdf> [Accessed: February 10, 2017], doi: $10.2139 /$ ssrn. 1494324 .

Hájek, O., Novosák, J., Zahradník P., Bednáŕ, P. (2012) "Regionální disparity a financování regionální politiky - některé poznatky z České republiky", Politická ekonomie, Vol. 60, No. 3, pp. 330-348, doi: 10.18267/j.polek.845. 
Hartšenko, J., Sauga, A. (2013) "The role of financial support in SME andeconomic development in Estonia", BEH - Business and Economic Horizons, Vol. 9, No. 2, pp. 10-22, doi: 10.15208/beh.2013.6.

Hohti, S. (2000) "Job Flows and Job Quality by Establishment Size in the Finnish Manufacturing Sector 1980-94", Small Business Economics, Vol. 15, No. 4, pp. 265-281, doi: 10.1023/a:1011100911645.

Holienka M., Pilková A., Ostapenko N. (2016) "Entrepreneurial Environment and Economic Growth: What Affects the Productiveness of Business Activity at Macro Level?"“. In Dudycz T., Osbert-Pociecha G., Brycz B. (eds), The Essence and Measurement of Organizational Efficiency. Springer Proceedings in Business and Economics. Springer, Cham, doi: 10.1007/978-3-319-21139-8_6.

Holtz-Eakin, D., Kao, C. (2003) "Entrepreneurship and Economic Growth: The Proof is in the Productivity", Working Paper No. 50. Center for Policy Research, Syracuse University, Syracuse, NY, doi: 10.2139/ssrn.1809885.

Ionescu, R., Tudor, F. (2011) "Modeling the impact of the european cohesion policy under the present crisis", Economics, Management, and Financial Markets, Vol. 6, No. 2. pp. 853-867.

Kirchhoff, B. A., Phillips, B. D. (1988) "The Effect of Firm Formation and Growth on Job Creation in the United States", Journal of Business Venturing, Vol. 3, No. 4, pp. 261-272, doi: 10.1016/0883-9026(88)90008-0.

Klette, T. J., Mathiassen, A. (1996) "Job Creation, Job Destruction and Plant Turnover in Norwegian Manufacturing", Annales d'Economie et de Statistique, Vol. 41-42, pp. 97-125.

Levin, A., Lin, C. F., Chu, C. S. J. (2002) "Unit root tests in panel data: asymptotic and finite-sample properties", Journal of Econometrics, Vol. 108, No. 1, pp. 1-24, doi: 10.1016/s0304-4076(01)00098-7.

Lima, M. C., Cardenete, M. A. (2008) "The impact of European Structural Funds in the South of Spain", European Planning Studies, Vol. 16, No. 10, pp. 14451457, doi: 10.1080/09654310802420169.

Lukeš, M. (2013) "Entrepreneurs as Innovators: A Multi-Country Study on Entrepreneurs' Innovative Behaviour", Prague Economic Papers, Vol. 22, No. 1, pp. 72-84, doi: 10.18267/j.pep.441.

Martin, R. (2003) "The Impact of the EU's Structural and Cohesion Fund on Real Convergence in the EU", NBP Conference "Potential Output and Barriers to growth" Zalesie Górne, [Internet] Available at: <pki.nbp.pl/konferencje/zalesie/ pdf/martin.pdf $>$ [Accessed: December 13, 2015].

Martin, R., Tyler, P. (2006) "Evaluating the Impact of the Structural Funds on Objective 1 Regions: An Explanatory Discussion”, Regional Studies, Vol. 40, No. 2, pp. 201-210, doi: 10.1080/00343400600600546.

Mason, C. (1983) "Some definitional difficulties in new firms' research", Area, Vol. 15, No. 1, pp. 53-60. 
Mohl, P., Hagen, T. (2008) "Does EU Cohesion Policy promote growth? Evidence from Regional Data and Alternative Econometric Approaches", ZEW Discussion Papers, [Internet] Available at: <www: ftp://ftp.zew.de/pub/zewdocs/dp/dp08086.pdf $>$ [Accessed: October 22, 2016], doi: https://doi. org/10.2139/ssrn.1298935.

-- (2010) "Do EU Structural Funds Promote Regional Growth? New Evidence from Various Panel Data Approaches", Regional Science and Urban Economics, Vol. 40, No. 5, pp. 353-365, doi: 10.1016/j.regsciurbeco.2010.03.005.

MPO (2016) Data obtained from the Ministry of Industry and Trade. [Accessed: February 25, 2016].

National Training fund (2010) "Vliv kohezní politiky na úroveň a kvalitu zaměstnanosti v České republice", [Internet] Available at: <http://s-f.cz/ getmedia/ccfb9796-60ac-4fc1-8f03-19d5eb06983a/MMR_Vliv-koheznipolitiky_zamestnanost_V4_ccfb9796-60ac-4fc1-8f03-19d5eb06983a.pdf?ext=. pdf $>$ [Accessed: October 10, 2016].

Nyström, K. (2008) "Is Entrepreneurship the Salvation for Enhanced Economic Growth", CESIS Electronic Working Paper Series, Paper No. 143.

Pereira, A. M., Gaspar, V. (1999) "An Intertemporal Analysis of Development Policies in the EU", Journal of Policy Modeling, Vol. 21, No. 7, pp. 799-822, doi: 10.1016/s0161-8938(98)00020-9.

Puigcerver-Peñalver, M.C. (2007) "The Impact of Structural Funds Policy on European Regions'Growth. A Theoretical and Empirical Approach", The European Journal of Comparative Economics, Vol. 4, No. 2, pp. 179-208.

Rodríguez-Pose, A., Fratesi, U. (2004) "Between Development and Social Policies: The Impact of European Structural Funds in Objective 1 Regions", Regional Studies, Vol. 38, No. 1, pp. 97-113, doi: 10.1080/00343400310001632226.

Romero, I. (2011) "Analysing the composition of the SME sector in high- and lowincome regions: some research hypotheses", Entrepreneurship and Regional Development, Vol. 23, No. 7-8, pp. 637-660, doi: 10.1080/08985626.2010. 491872.

Rusu, V. D., Roman, A. (2017) "Entrepreneurial Activity in the EU: An Empirical Evaluation of Its Determinants", Sustainability, Vol. 9, No. 10, pp. 1679, doi: $10.3390 /$ su9101679.

Sauka, A. (2014) "Measuring the competitiveness of Latvian companies", Baltic Journal of Economics, Vol. 14, No. 1-2, pp. 140-158, doi: 10.1080/1406099x. 2014.995421.

Smékalová, L., Janíček, P., Škarka, M., Kozák, V. (2015) “Spatial Concentration of the Cohesion Policy Projects in Nationally Delimitated Intervention Areas: The Case of the Czech Republic and Poland", Economics and Sociology, Vol. 8, No. 2, pp. 211-226, doi: 10.14254/2071-789x.2015/8-2/15. 
Sternberg, R. (2012) "Do EU Regional Policies Favour Regional Entrepreneurship? Empirical Evidence from Spain and Germany", European Planning Studies, Vol. 20, No. 4, pp. 583-608, doi: 10.1080/09654313.2012.665030.

Supreme Audit Office (2016) "Kontrolní závěr z kontrolní akce 16/01. Peněžní prostředky Evropské unie a státního rozpočtu určené na financování opatření v rámci operačního programu Podnikání a inovace z hlediska dosažení cílů", [Internet] Available at: <http://www.nku.cz/assets/kon-zavery/k16001.pdf> [Accessed: January 10, 2017].

Šebestová, J., Klepek, M., Čemerková, Š., Adámek, P. (2015) "Regional Entrepreneurship Culture and the Business Lifecycle: Patterns from the MoravianSilesian Region", Acta Universitatis Agriculturae et Silviculturae Mendelianae Brunensis, Vol. 63, No. 6, pp. 2137-2144, doi: 10.11118/actaun201563062137.

Šumpíková, M., Pavel, J., Klazar, S. (2003) "EU Funds: Absorption Capacity and Effectiveness of Their Use, with Focus on Regional Level in the Czech Republic. Conference on Problems facing the New Member States", [Internet] Available at: $<$ http://unpan1.un.org/intradoc/groups/public/documents/nispacee/ unpan01854> [Accessed: January 16, 2017].

Tang, L., Koveos, P. E. (2004) "Venture entrepreneurship, innovation entrepreneurship and economic growth", Journal of Developmental Entrepreneurship, Vol. 9, No. 2, pp. 161-171.

Vaidere, I. (2011) "The impact of regional and cohesion policy on the economic development of the EU", European Integration Studies, Vol. 5, pp. 165-171, doi: 10.5755/j01.eis.0.5.1092.

Van Stel, A., Carree, M., Thurik, R. (2005) "The effect of entrepreneurial activity on national economic growth", Working paper series of EIM Business and Policy Research", [Internet] Available at: <http://www.entrepreneurship-sme. eu/pdf-ez/N200419.pdf $>$ [Accessed: January 25, 2016].

Veber, J.et al. (2012) Podnikání malé a střední firmy, Praha: Grada Publishing.

Verbeek, M. (2012) A guide to modern econometrics, 4th ed. Chichester: Wiley.

Wokoun, R., Kolařík, P., Kolaříková, J. (2016) "Evaluation of Entrepreneurs with a Focus on Operational Programme Enterprise and Innovation (OPEI). Results of a Questionnaire Survey", Economics and Sociology, Vol. 9, No. 4, pp. 272-288. Wooldridge, J. M. (2013) Introductory econometrics: a modern approach, Mason: South-Western/Cengage Learning. 


\title{
Ekonomska učinkovitost regija NUTS III u Češkoj u kontekstu poduzetničkih subvencija iz strukturnih fondova $\mathrm{EU}_{-1}{ }^{1}$
}

\author{
Jana Kolařiková ${ }^{2}$, Ondřej Dvouletý ${ }^{3}$, Petr Kolařik ${ }^{4}$
}

\begin{abstract}
Sažetak
Poduzetništvo se smatra jednim od ključnih čimbenika gospodarskog rasta, a politika poduzetnišstva smatra se značajnim doprinosom regionalnom gospodarskom razvoju. Cilj ovog rada je utvrditi utječu li stopa nezaposlenosti i BDP-a po stanovniku NUTS III regije u Češkoj na iznos financijskih subvencija koje se plaćaju poduzećima iz Operativnog programa poduzetništva i inovacija (OPEI). U radu se koriste regresijska analiza $i$ Grangerov test kauzalnosti kako bi se procijenila postavljena hipoteza. Rezultati korištenja ekonometrijskih modela potvrđuju statistički značajan pozitivan utjecaj OPEI subvencija, uz vremensku odgodu od jedne godine, na rast NUTS III BDP-a po glavi stanovnika. Hipoteza koja pretpostavlja negativan utjecaj OPEI subvencija na promjene regionalne stope nezaposlenosti, također je u početku statistički potvrđena i također s vremenskim odgodom od jedne godine. Međutim, nismo uspjeli potvrditi statistički značajni početni utjecaj subvencija OPEI-a na rast BDP-a po glavi stanovnika.
\end{abstract}

Ključne riječi: regionalni razvoj, regresijska analiza, Grangerov test kauzalnosti, strukturna sredstva, politika poduzetništva

JEL klasifikacija: R12, R58, L26, L53

${ }^{1}$ Istraživanje je provedeno uz potporu Interne agencije za financijske potpore Sveučilišta ekonomije u Pragu u okviru projekta F5 / 69/2017 i unutar projekta FBA br. IP300040.

2 Poslijedoktorandica i predavačica, University of Economics, Prague, Faculty of Economics, Department of Regional Studies, Winston Churchill Sq. 4, 13067 Prag 3, Republika Češka. Znanstveni interes: regionalni razvoj, regionalna analiza. Tel.: +420 224095 518, Fax: +420 224095 546.E-mail:xtomj38@vse.cz.

${ }^{3}$ Poslijedoktorandica i predavačica, University of Economics, Prague, Faculty of Business Administration, Department of Entrepreneurship, Winston Churchill Sq. 4,130 67 Prag 3, Republika Češka. Znanstveni interes: evaluacija poduzetničke politike, odrednice poduzetništva, poduzetnička ekonomija.Tel.: +420728431027.E-mail: ondrej.dvoulety@vse.cz.

4 Doktorandica, University of Economics, Prague, Faculty of Economics, Department of Regional Studies, Winston Churchill Sq. 4, 13067 Prag 3, Republika Češka. Znanstveni interes: poduzetništvo, regionalna politika, regionalni razvoj. Tel.: +420 224095 518, Fax: +420224095 546.E-mail: xkolp29@vse.cz (osoba za kontakt). 